\title{
Operational Capabilities: The Secret Ingredient
}

\author{
Sarah Jinhui $\mathrm{Wu}^{\dagger}$ \\ Fordham University, 463 Faber Hall, 441 E. Fordham Rd., Bronx, NY 10458, \\ e-mail: jiwu@fordham.edu
}

Steven A. Melnyk

Eli Broad College of Business, Michigan State University, 327 North Business Complex, East Lansing, MI 48824-1122, e-mail: melnyk@msu.edu

\section{Barbara B. Flynn}

Kelley School of Business, Indiana University, 801 W. Michigan St., BS 4010, Indianapolis, IN 46033,e-mail: bbflynn@indiana.edu

\begin{abstract}
We develop a theoretical definition of operational capabilities, based on the strategic management and operations management literature, and differentiate this construct from the related constructs of resources and operational practices, drawing upon the resourcebased view of the firm as our foundation. We illustrate the key features of operational capabilities using the illustration of a restaurant kitchen. Because the traits of operational capabilities are distinct, they create a barrier to imitation, making them a potential source of competitive advantage. However, operational capabilities are particularly challenging to measure, because they emerge gradually and are tacit, embedded, and manifested differently across firms. In solving this measurement conundrum, we draw upon similar situations experienced by Schein (2004) and Eisenhardt and Martin (2000) in operationalizing organizational culture and dynamic capabilities. A taxonomy of six emergent operational capabilities is developed: operational improvement, operational innovation, operational customization, operational cooperation, operational responsiveness, and operational reconfiguration. A set of measurement scales is developed, in order to measure each of the operational capabilities, and validated using two different datasets. This allows replication of the psychometric properties of the multi-item scales and helps to ensure the validity of the resulting measures.
\end{abstract}

Subject Areas: Capabilities, Competitive Advantage, Competitive Strategy, Dynamic Capabilities, Operational Capabilities, Operational Cooperation, Operational Customization, Operational Improvement, Operational Innovation, Operational Practices, Operational Reconfiguration, Operational Responsiveness, Operations Strategy, Resources, Resource-Based View, Strategic Decision Making, and Survey Research.

\footnotetext{
$\dagger$ Corresponding author.
} 


\section{INTRODUCTION}

The need to develop and maintain a sustainable competitive advantage is at the foundation of operations strategy, which draws on a number of intertwined yet distinct elements, including organizational capabilities, practices, and resources. Seminal strategic management research (Penrose, 1959; Wernerfelt, 1984; Barney, 1991; Peteraf, 1993) provides a well-developed theoretical framework for understanding how a sustainable competitive advantage arises from the unique and heterogeneous resources of a firm, and operations management researchers have long focused on various operational practices for performance improvement (Flynn, Sakakibara, \& Schroeder, 1995; Kotha \& Swamidass, 2000; Cua, McKone, \& Schroeder, 2001; Gupta \& Whitehouse, 2001; Shah \& Ward, 2003). Yet, there is considerable disagreement regarding what constitutes an organizational capability and what does not (Zahra, Sapienza, \& Davidson, 2006; Schreyogg \& KlieschEberl, 2007; Lee \& Kelley, 2008). The literature is "riddled with inconsistencies, overlapping definitions and outright contradictions" (Zahra et al., 2006, p. 917), and the term "capabilities" is sometimes used interchangeably with terms such as "resources" and "competencies" (Hayes, Pisano, Upton, \& Wheelwright, 2005; Größler \& Grübner, 2006). In this article, we focus on operational capabilities, which are a subset of the broader construct of organizational capabilities, in order to establish tangible bounds for clearly differentiating operational capabilities from related constructs.

The resource-based view (RBV) of the firm (Penrose, 1959; Barney, 1991; Peteraf, 1993) provides the foundation for our work. Based on the assumption of heterogeneous resources across firms, RBV emphasizes the organizational capabilities that underlie a firm's ability to excel in achieving its competitive priorities (Coates \& McDermott, 2002). Critical to this is a firm's unique combination of resources and organizational capabilities; the potential for competitive advantage is related to the extent to which they are valuable, rare, inimitable, and nonsubstitutable (Dierickx \& Cool, 1989; Barney, 1991, 1995). RBV suggests that operational capabilities are particularly relevant because internal resources and capabilities are the foundation for a firm's strategy; they are the primary source of profit and provide a stable basis for defining a firm's identity (Colotta, Shi, \& Gregory, 2003).

Operational capabilities are the "secret ingredient" in explaining the development and maintenance of competitive advantage. However, they are often overlooked because they are tightly embedded in the organizational fabric of an operations system. Decision makers' attention tends to be drawn to more obvious assets, such as resources and operational practices. In addition, there is confusion regarding what an operational capability is and what differentiates operational capabilities from resources or practices, because they are closely related. Consequently, much of the impact of operational capabilities is often attributed to resources or operational practices. Because they emerge gradually and are tightly associated with a firm's distinctive features, operational capabilities tend to blend into the background. Yet, the traits of operational capabilities are distinct and create a barrier to imitation, making them a potential source of competitive advantage. 
There is a need for research that provides a sound theoretical foundation of operational capabilities. Without understanding their role, we risk having an incomplete understanding of the process by which competitive advantage is developed. Specifically, this study will:

- Provide a theoretically based definition of operational capabilities and use it to highlight the major differences between operational capabilities and related concepts.

- Develop, validate, and empirically test a measurement instrument for operational capabilities.

We draw on the strategic management literature on organizational capabilities, applying it to the context of operations management to develop a definition of operational capabilities. We then illustrate the key features of operational capabilities using the illustration of a restaurant kitchen. We develop a set of measurement scales, which we validate, using two different datasets. This allows replication of the psychometric properties of the multi-item scales, helping to ensure the validity of the resulting measures.

\section{THEORETICAL FOUNDATION}

\section{Organizational Capabilities: The Broader Construct}

We begin by reviewing the literature on the broader construct of organizational capabilities and discussing their key traits. We view operational capabilities as a subset of the organizational capabilities construct, and believe that insights gained from research on organizational capabilities can be readily applied to the study of operational capabilities. Several researchers define organizational capabilities as a higher level construct that builds on the interaction of resources. For example, Amit and Schoemaker (1993, p. 35) define organizational capabilities as "information-based tangible or intangible processes that are firm specific and are developed over time through complex interactions among the firm's resources," and Winter (2000, p. 983) states that, "an organizational capability is a high-level routine or collection of routines that, together with its implementing input flows, confers upon an organization's management a set of decision options for producing significant outputs of a particular type." Others focus on the competitive potential of organizational capabilities, describing them as anything that can be thought of as a firm's strength (Wernerfelt, 1984), "potential behavior modes of a plant with which it can support and shape corporate strategy and help it to succeed in the marketplace (Größler \& Grübner, 2006, p. 458)," and "a bundle of aptitudes, skills and technologies that a firm performs better than its competitors, that is difficult to imitate and provides an advantage in the marketplace" (Coates \& McDermott, 2002, p. 436). Thus, organizational capabilities provide the means for configuring an organization's resources (Eisenhardt \& Martin, 2000; Lee \& Kelley, 2008), and there is consensus that they deal with a firm's capacity to deploy resources and achieve specific goals.

In contrast, resources are stocks of factors that are owned or controlled by a firm (Amit \& Schoemaker, 1993) and which are the inputs into the production 
process. Resources can be tangible (financial and physical resources), intangible (technology, reputation, and culture), or human (specialized skills and knowledge, communication, and motivation). Grant (1991) describes resources as nouns, because they can lie dormant, like an idle plant or unused knowledge, until they are needed, and can be defined independently of their use. Thus, a resource is something that a firm has access to, rather than something that it can do (Größler \& Grübner, 2006).

Organizational capabilities, on the other hand, represent a distinctive and superior way of deploying, allocating, and coordinating resources (Amit \& Schoemaker, 1993; Cavusgil, Seggie, \& Talay, 2007; Schreyogg \& Kliesch-Eberl, 2007). Grant (1991) describes organizational capabilities as verbs, because they focus on the way in which resources are used (Penrose, 1959); without organizational capabilities, a resource may lose its value over time (Coates \& McDermott, 2002). Although organizational capabilities focus on the aptitude for managing a process or managing intellectual property, resources are the actual factory, brand, or patent (Coates \& McDermott, 2002).

Organizational capabilities can be purposely built by focusing on the complex interactions between a firm's resources (Dierickx \& Cool, 1989; Amit \& Schoemaker, 1993), deeply rooted within its idiosyncratic social structure (Schreyogg \& Kliesch-Eberl, 2007), and spanning functions and hierarchical levels (Grant, 1996; Zeitz, Mittal, \& McCauly, 1999). As such, organizational capabilities become embedded into the fabric of a firm through managers' deliberate decisions over time (Grewal \& Slotegraaf, 2007). Specifically, organizational capabilities are embedded in organizational processes focused on coordination, learning, and transformation (Harreld, O'Reilly, \& Tushman, 2007). They are complex in nature and involve both internal and external processes (Hofer \& Schendel, 1978; Dosi, Nelson, \& Winter, 2000; Schreyogg \& Kliesch-Eberl, 2007). The relevant knowledge and abilities are held collectively, supported by social networks, rather than residing in a single individual (Pandza, Polajnar, Buchmeister, \& Thorpe, $2003 b$ ). Because they cannot be transferred to other firms the way that some resources can, the embeddedness of organizational capabilities in a firm's processes and routines provides a potential source of competitive advantage. Narasimhan, Swink, and Kim (2005) emphasize that, although organizational capabilities are the "exploitation of specific practices to attain performance gains," investment in practices, per se, does not constitute organizational capabilities. It is possible for two plants to invest equally in the same practices and not be capable to the same degree, in terms of manufacturing performance outcomes.

Thus, organizational capabilities are tacit social processes that emerge gradually over time, so gradually that participants may not even be aware of their existence and ultimately take them for granted (Leonard-Barron, 1992). As social processes, organizational capabilities are path dependent, influenced by factors such as firm history (Teece, Pisano, \& Shuen, 1997), actions of decision makers (Rothaermel \& Hess, 2007), and the firm's learning process (Schreyogg \& KlieschEberl, 2007). Furthermore, these paths are unique to a firm (Teece et al., 1997), described by Eisenhardt and Martin (2000) as "equifinality"; there are multiple paths to achieving the same organizational capability. Thus, the paths to a specific organizational capability can arise from very different starting points (Mosey, 
2005). Organizational capabilities are not necessarily independent, however; in fact, an organizational capability may be more valuable when it is combined with other organizational capabilities (Ordanini \& Rubera, 2008).

Organizational capabilities provide a collective process of making sense of the environment (Schreyogg \& Kliesch-Eberl, 2007), providing a firm with a means of configuring its resources at various levels (Lee \& Kelley, 2008). Organizational capabilities facilitate problem-solving decision making under conditions of uncertainty (Dosi, Hobday, \& Marengo, 2003), allowing managers to deal with ambiguous and ill-structured tasks (Schreyogg \& Kliesch-Eberl, 2007). They are empirically validated through a process of identifying problems, applying embedded skill sets and verifying that the desired results have been attained.

To summarize, organizational capabilities:

- Are firm specific,

- Emerge gradually over time,

- Are tacit; participants may be unaware of their existence,

- Are path dependent, influenced by a firm's history and the actions of its decision makers, and

- Are empirically validated, through their application to problems faced by a firm.

\section{Operational Capabilities: Defining the Construct}

Operations management researchers have long been intrigued by RBV and its potential implications for operations strategy (Amundson, 1998), particularly the concept of organizational capabilities. The "introverted orientation" (Pandza, Horsburgh, Gorton, \& Polajnar, 2003a) of RBV enables it to "emancipate the neglected strategic importance of operations." However, operations strategy research has focused primarily on defining operational capabilities or prescribing how they should be built. Although the strategic management literature focuses primarily on paths to competitive advantage, there has been less research related to processes that enable coordination/integration, learning, and reconfiguration (Teece, 2007), which lie squarely in the domain of operations management (Mosey, 2005). Operations management researchers have found the application of the organizational capabilities construct to operations strategy challenging:

While this is undoubtedly of value, academics are less willing to confront those attributes of RBV that make the perspective less operational, such as the idiosyncrasy, path dependency and context dependency of a capability. They recognize the dynamics of capacity accumulation, yet do not explore it (Pandza et al., 2003b, p. 823).

We believe that the concept of organizational capabilities is directly relevant to operations strategy. Resources form a plant's foundation, consisting of the plant's capacity and all of its stocks (Wang \& Ahmed, 2007). In contrast, operational practices such as just in time are fairly standardized activities, programs, or procedures that have been developed to address the attainment of specific operational goals or objectives (Flynn et al., 1995). Operational capabilities provide unity, integration, 
and direction to resources and operational practices. They encapsulate both explicit elements (e.g., resources, practices) and tacit elements (e.g., know-how, skill sets, leadership) for handling a variety of problems or dealing with uncertainty. That is, operational capabilities draw on resources and operational practices to generate outcomes consistent with desired results, helping a plant develop solutions that make sense. Based on the perspectives of organizational capabilities in the strategic management literature, we apply their essential traits to the functional domain of operations management, offering the following definition:

Operational capabilities are firm-specific sets of skills, processes, and routines, developed within the operations management system, that are regularly used in solving its problems through configuring its operational resources.

\section{Operational Capabilities: An Illustration}

It is crucial to differentiate the operational capabilities construct from interrelated constructs, particularly operational practices, which are emphasized in the operations strategy literature, and resources, emphasized in the strategic management literature. However, this has proven to be challenging for operations strategy researchers over time. "Any discussion of capabilities is ... open to criticism of its ambiguity and its inability to provide clear definitions, obvious examples and straightforward prescriptions" (Pandza et al., 2003b, p. 824). We address this using the example of a restaurant kitchen.

\section{Resources}

A kitchen's resources include both tangible and intangible assets, such as stoves and the skill level of the kitchen staff, which determine the bounds of what can and cannot be done in the kitchen. However, resources, by themselves, only define potential, because they are passive and reactive, like a stick of dynamite. Nothing happens to dynamite until it is lit; similarly, a stove cannot prepare a meal.

\section{Operational practices}

Operational practices are essentially recipes, providing generic instructions on how various resources can be combined to generate a meal. Once a process has been documented as a recipe, it becomes a standard solution. However, although many kitchens may have the same chocolate mousse recipe, there is no guarantee that the resulting mousses will all taste the same. In fact, it is not surprising to see that the creaminess of the ensuing mousses is different, because a recipe only provides basic guidance about how to combine resources; it does not capture the impact of less tangible factors, such as the freshness and quality of the ingredients or skill in setting the stove's flame at the proper height.

\section{Operational capabilities}

A kitchen's operational capabilities are the capacity to leverage the staff's skill sets to deploy resources in creating dishes that reflect the restaurant's history, style of cooking, and the preferences of its customers. Although the chef is a critical resource, he needs to customize his cooking school training to the restaurant's specific context (menu, affordability, cuisine history, customers' needs, etc.). The 
restaurant itself has a history that has shaped its character, making it unique. A kitchen's operational capabilities are firm specific (not person specific), and the chef would not be able to easily transfer them to another restaurant. Graduating from a well-known cooking school may get a new chef in the door, but he still needs to master what makes the kitchen unique, observing interactions and picking up clues from the kitchen's context. The kitchen's operational capabilities are passed on to future generations through apprenticeships, illustrating path dependence. They are developed in a system where various resources interact in a harmonious way, which takes time to develop; thus, they emerge gradually over time.

A chef can easily write down a specific recipe, for example, for roast duck. However, the chef would be hard pressed to articulate the subtleties of making roast duck, because he has taken many things for granted over the years and they seem like second nature to him. These are the necessary but intangible elements associated with the kitchen's operational capabilities. Thus, the capabilities of the kitchen are tacit and deeply embedded. The existence of operational capabilities is reflected in the kitchen's ability to solve its primary strategic problem. For example, the famous QuanJuDe (全聚德) in Beijing has long been regarded as the best Peking Duck restaurant in the world. The uniqueness of its roast duck comes from a cooking process that integrates explicit resources, practices and tacit elements (know-how, skill sets, leadership) which have become institutionalized. Over the hundred year history of QuanJuDe, neither the ingredients nor the recipe for roast duck have changed. Yet, QuanJuDe has updated its process to allow preparing roast duck faster for today's time-stressed customers, while retaining the original flavor. Its operational capability has been empirically validated through the reactions of the diners to traditional roast duck prepared using updated methods.

\section{TAXONOMY OF OPERATIONAL CAPABILITIES}

We used the literature to identify a set of emergent operational capabilities. Our starting point was the work of Swink and Hegarty (1998), who proposed seven capabilities relevant to product differentiation in an operations context. Several of these capabilities require further refinement, in terms of their dimensionality, uniqueness, and applicability to operations management; thus, we supplemented them with perspectives drawn from additional literature.

\section{Emergent Operational Capabilities \\ Operational improvement}

Operational improvement is differentiated sets of skills, processes, and routines for incrementally refining and reinforcing existing operations processes. Its focus is on incremental process change, creating the small wins that translate into superior performance, which requires very different processes and resource configurations than large scale, radical process changes (Peng, Schroeder, \& Shah, 2008). Operational improvement applies current technical capabilities to systematically seek and develop new ways of doing work for existing customers (Benner \& Tushman, 2003). Although managers have long recognized the importance of operational capabilities related to continuous improvement, many have found its management 
to be challenging (Anand, Ward, Tatikonda, \& Schilling, 2009); thus, operational improvement capability is related to competitive advantage. Although it focuses on measurable, short-term benefits (Harrington \& Mathias, 1997; Mukherjee, Lapré, \& Van Wasenhove, 1998), its cumulative effect can be quite significant, benefitting future generations of products as well as existing products (Wheelwright \& Hayes, 1985). Operational improvement is related to Benner and Tushman's (2003) "exploitation," which focuses on skills, processes, and routines related to refinement, implementation, efficiency, production, and selection (Peng et al., 2008). Operational improvement is path dependent, because past innovation activities play a role in future innovation (Benner \& Tushman, 2003).

\section{Operational innovation}

In contrast to the routine, incremental focus of operational improvement, operational innovation is differentiated sets of skills, processes, and routines for radically improving existing operations processes or creating and implementing new and unique operations processes. Because operational improvement builds upon existing organizational abilities, it is unlikely to lead to innovations that significantly depart from existing technological or market competencies (Sitkin \& Stickel, 1996). However, operational innovation focuses on searching for variance and experimentation, in order to change technology trajectories and associated organizational competencies (Benner \& Tushman, 2003). The focus of operational innovation is on large scale, radical process changes through new knowledge or departures from existing skills (Benner \& Tushman, 2003), which requires very different processes and resource configurations than incremental changes to existing processes (Peng et al., 2008). Operational innovation is related to Benner and Tushman's (2003) "exploration," which focuses on skills, processes, and routines related to search, discovery, experimentation, and implementation.

\section{Operational customization}

Schroeder, Bates, and Junttila (2002) found that the operational capabilities inherent in firm-specific, path-dependent learning resulted in the development of proprietary processes that confer competitive advantage. Although there are many different practices associated with the development of proprietary processes, each reflects an underlying ability to customize a process to meet the unique needs of a firm's products and target markets. Operational customization is differentiated sets of skills, processes, and routines for the creation of knowledge through extending and customizing operations processes and systems. Operational customization has its roots in the work of Wheelwright and Hayes (1985), who describe the development of proprietary processes as one of their "acid tests" for determining whether a firm has world class operations. Through the development of proprietary processes, a firm benefits in two ways. First, it develops equipment and processes that are difficult for competitors to imitate. Perhaps more importantly, it develops employees' ability to maintain and improve equipment and processes, allowing them to know more than even their equipment suppliers about all that is critical to their business (Wheelwright \& Hayes, 1985). 


\section{Operational cooperation}

Swink and Hegarty (1998) described "integration" as the ability to coordinate between manufacturing and the product-process design function. This is part of a broader operational capability that we call operational cooperation, which includes the ability to create and sustain healthy relationships with supply chain members, related to sourcing products (Kim, 2006). Operational cooperation is the ability to bring involved parties together to share information, converging on a shared interpretation of what needs to be done. As uncertainty increases, the need for operational cooperation capability increases, to help firms cope with the fuzziness of their environments and enact a shared vision, in order to acquire information, share views, interpret the task environment, resolve cross-functional or interorganizational conflicts, and reach a mutual understanding of a task. The rationale for operations cooperation is based on information processing theory (Galbraith, 1973, 1979; Flynn \& Flynn, 1999), which focuses on mechanisms for dealing with the complexities of competing in a global environment and using advanced technologies. Sources of complexity include goal diversity (variety of products, markets served, individual product volumes) (Bozarth, Warsing, Flynn, \& Flynn, 2009), customer diversity (size of customer base, characteristics of customer relationships, volumes purchased by various classes of customers, distance to customers) (Anderson \& Narus, 1998), supplier diversity (number of suppliers, nature of the relationship with specific suppliers, location of suppliers) (Landry, 1998; Gonzalez-Benito, 2007; Koufteros, Cheng, \& Lai, 2007; Holweg \& Pil, 2008; Narasimhan \& Talluri, 2009), labor diversity (number of job classifications, employee layoffs), and manufacturing diversity (shifts in monthly sales, prevalence of expediting, number of levels in the bill of materials). In response to this increasing complexity and equivocality, firms seek coordinating mechanisms (Koufteros, Vonderembase, \& Doll, 2002; Bozarth et al., 2009), which allow them to process more information and to do so quickly.

\section{Operational responsiveness}

Operational responsiveness is the differentiated skills, processes, and routines for reacting quickly and easily to changes in input and output requirements, so that a process can consistently meet customer requirements with little time or cost penalty (Swink, Narasimhan, \& Kim, 2005). Underlying this capability is the ability to manage production resources such as machine, labor, materials handling, and production sequencing in light of uncertainty. This capability is closely related to technological and production expertise in the current operations system (Zhang, Vonderembse, \& Lim, 2003), which lay the foundation for flexibility performance. Specifically, operational responsiveness allows a plant to operate at various batch sizes or produce at different production output levels (i.e., volume flexibility), based on differentiated skills, processes and routines for flattening a firm's cost curve over a wide range of production volumes. Operational responsiveness allows a firm to produce different combinations of products (mix flexibility), given its fixed capacity (Martinez Sanchez \& Perez Perez, 2005), based on differentiated skills, resources, and routines for quickly responding to changes in inputs or output 
requirements. Thus, operational responsiveness enables a firm to produce both the volume and the kinds of products that customers want, in a timely manner.

\section{Operational reconfiguration}

Although operational responsiveness focuses on using existing operations resources to deal with change, operational reconfiguration focuses on reshaping (investing and divesting) operations resources to catch up with environmental changes. Operational reconfiguration is based on the concept of dynamic capabilities. Pioneered by Teece et al. (1997) the dynamic capabilities approach (DCA) builds upon RBV's foundation (Pandza et al., 2003b), focusing on the dynamic process of how firms develop capabilities in response to shifts in their business environment (Pandza et al., 2003a). Where RBV focuses on durable performance differences between firms due to asymmetric resource endowments and productivities, DCA describes firms' differing abilities to accumulate, deploy, renew, and reconfigure resources in response to changes in their external environment (Pandza et al., 2003a). Dynamic capabilities are "the firm's processes that use resources-specifically the processes to integrate, reconfigure, gain, and release resources - to match and even create market change" (Eisenhardt \& Martin, 2000, p. 1107). Dynamic capabilities are thus the means by which firms achieve new resource conditions as markets emerge, collide, split, evolve, and die. Operational reconfiguration, then, is differentiated sets of skills, processes, and routines for accomplishing the necessary transformation to re-establish fit between operations strategy and the market environment, when their equilibrium has been disturbed, which is valuable when a firm is faced with a rapidly changing external environment (Teece et al., 1997). Operations reconfiguration evolves from routines that sense unexpected changes, maintain flexible responses, and implement synchronized operations. Pandza et al. (2003a) describes operational reconfiguration as the ability to invest in physical and intangible resources that provide a firm with contingencies in uncertain environments, so that it can alter its course of action in light of new information. It is illustrated by the ability to adapt manufacturing strategy to changes in market demand, increased global fragmentation, competition, rapid technological advancement, stage of product life cycle, and corporate strategy (Cagliani, Acur, \& Boer, 2006; Swafford, Ghosh, \& Murthy, 2006). Operational reconfiguration is important in uncertain and volatile business environments, where firms face new innovations, economic crises, production losses, political events, and so forth, such that the ability to sense and deal with change becomes a way of life.

Table 1 summarizes our initial taxonomy of operational capabilities. The next step was to refine and empirically validate the resulting definitions through the use of a focus group of experienced operations managers.

\section{Focus Group}

The focus group assessed whether the taxonomy of operational capabilities adequately reflected the perceptions of managers. The participants consisted of eight middle level managers who worked primarily in the operations area in a single firm. On average, they had worked in operations and supply chain management 


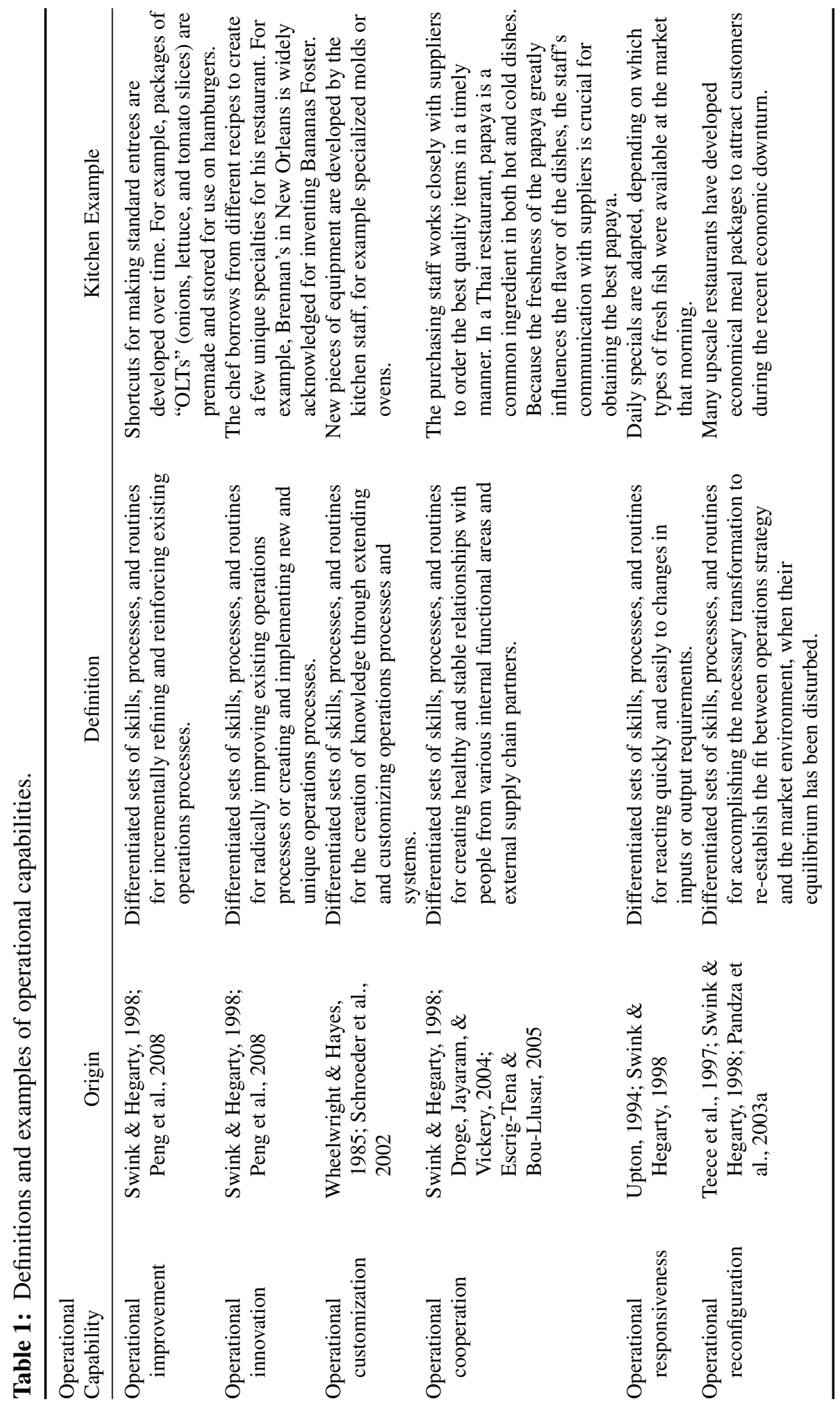


Table 2: Operational capabilities identified from the literature and by the focus group.

\begin{tabular}{ll}
\hline Focus Group & \multicolumn{1}{c}{ Literature } \\
\hline $\begin{array}{l}\text { Collaboration and trust with partners } \\
\text { Intellectual property and know-how (specialized tooling, } \\
\text { technology, equipment) }\end{array}$ & $\begin{array}{l}\text { Operational cooperation } \\
\text { Operational customization }\end{array}$ \\
$\begin{array}{l}\text { Specialization (service experts) } \\
\text { Process customization }\end{array}$ & \\
$\begin{array}{l}\text { Responsiveness } \\
\text { Sense of urgency to meet short lead time }\end{array}$ & Operational responsiveness \\
Fulfillment of customers' orders & \\
$\begin{array}{l}\text { Process improvement to make cost competitive } \\
\text { Process standardization }\end{array}$ & Operational improvement \\
Radical process innovation & \\
Change management & Operational innovation \\
New product testing facility & Operational reconfiguration \\
Control of the supply chain & Others \\
Value creation for core customers & \\
Dependability and reliability & \\
\hline
\end{tabular}

for 14.75 ( 8 years minimum, 25 years maximum). Five were employed at the plant level, with three at the division level. The number of plants/divisions they had worked for varied from one to six (mean $=2.25)$. Thus, they were knowledgeable about their firm and its operational capabilities.

The participants were introduced to the concept of operational capabilities, and then asked to list what they believed were key operational capabilities. They listed a total of 15 items (see Table 2). There was substantial agreement between the focus group and our list of operational capabilities, with 11 items mapping directly on our taxonomy of operational capabilities. The four items that did not correspond were carefully assessed, revealing that one actually represented an outcome, whereas the other three reflected organizational, rather than operational, capabilities. "Dependability and reliability" is a process outcome, not an operational capability, because it focuses on performance and not on the way in which performance is achieved. "Control of the supply chain" goes beyond the domain of operational capabilities, potentially including factors such as channel power, brand name, and unique technology. Although this may reflect an organizational capability, it is by and large not in the domain of operations management. Similarly, "value creation for core customers" and "new product testing facility" are organizational, rather than operational, capabilities. Thus, the original taxonomy was retained.

\section{Operational Capabilities: Operationalizing the Construct}

The traits that cause operational capabilities to be a source of competitive advantage are also difficult to precisely operationalize and measure. In resolving 
this research conundrum, we turn to research on other constructs that have traits that hinder empirical research, specifically Eisenhardt and Martin (2000)'s research on dynamic capabilities and Schein's (2004) work on organizational culture.

In their analysis of dynamic capabilities, Eisenhardt and Martin's (2000) resolution of similar measurement issues was their recognition that dynamic capabilities exhibit "commonalities in key features, idiosyncrasy in details" (Eisenhardt \& Martin, 2000, p. 1108). The common features of dynamic capabilities can be readily observed and measured. However, they noted that "the existence of common factors among effective dynamic capabilities does not, however, imply that any particular (dynamic) capability is exactly alike across firms" (Eisenhardt \& Martin 2000, p. 1109). Thus, although dynamic capabilities may be manifested differently across firms, they have common features at their core. The same thinking can be applied to operational capabilities: although they are firm specific, their common core features can be identified and measured.

Schein (2004) was faced with a similar problem in his study of organizational culture: how do you measure something (in his case, culture) that is embedded in a firm, emerges gradually over time, and is highly tacit, so that the participants themselves may not even be aware of its presence? Schein's resolution was the recognition that, although organizational culture is difficult to measure directly, it is possible to observe and measure certain visible attributes associated with it. By observing these visible attributes, we can impute the nature of the underlying organizational culture. Schein (2004) identified three levels of organizational culture. Artifacts are the phenomena that one sees, hears, or feels when encountering a group, including visible organizational structures and processes, whereas espoused beliefs and values are the strategies, goals, and philosophies of a group. Underlying assumptions are the tacit, unconscious, taken-for-granted beliefs, perceptions, thoughts, and feelings that are the ultimate source of values and action. Artifacts are the easiest to observe, while underlying assumptions are the most difficult. Because we are imputing the nature of the underlying operational capabilities by capturing what are essentially artifacts, we must recognize that this approach has certain methodological implications, related to dealing with a reflective latent variable construct (Jarvis, Mackenzie, \& Podsakoff, 2003). Building on the conceptual foundation provided by Eisenhardt and Martin (2000) and Schein (2004), we applied the following guidelines in developing our measurement model.

- When measuring operational capabilities, we should focus on their commonalities. Thus, measurement models will, by necessity, be incomplete, because we recognize that it is not possible to capture the idiosyncratic or firm-specific components of operational capabilities.

- When measuring commonalities, we should focus primarily on artifacts, which reflect a deeper underlying operational capability. Thus, instruments used to capture information from respondents must focus on perceptual, self-reported measures of operational capabilities. 


\section{SCALE DEVELOPMENT AND VALIDATION}

\section{Scale Development}

Unlike measurement of operational practices, where a large amount of existing research provides a good pool for item selection ( $\mathrm{Li}$, Rao, Ragu-Nathan, \& Ragu-Nathan, 2005; Shah \& Ward, 2007), empirical research on operational capabilities is sparse. We created an initial tentative measurement set, based on insights from our taxonomy and the relevant literature (Teece et al., 1997; Swink \& Hegarty, 1998; Sen \& Egelhoff, 2000; Schroeder et al., 2002; Subramaniam \& Youndt, 2005). We followed the basic principles suggested by Nunnally (1978) and Churchill (1979); that is, the items used to measure a construct should converge with each other, but diverge from the items that measure other constructs. To deal with the challenge of developing appropriate measurement items (Little, Lindenberger, \& Nesselroade, 1999) and covering the construct domain with the desired reliability and validity, we followed the two-stage approach described by Li et al. (2005) and Menor and Roth (2007). The first stage involved using a $Q$-sort analysis to assess initial content validity and refine the measurement items. In the second stage, confirmatory analysis assessed the psychometric properties of the new multi-item scales. The confirmatory analysis used two distinct samples, in order to enhance generalizability.

$Q$-sort methodology uses experts to sort the measurement items into groups, with each group corresponding to a predetermined factor or dimension (McKeown $\&$ Thomas, 1988). Two evaluation indices are normally used to measure interjudge agreement levels: Cohen's (1960) kappa and Moore and Benbasat's (1991) hit ratio. Cohen's kappa takes into account the agreement occurring by chance (Fleiss, 1981), as well as the percentage agreement, with a score greater than .65 considered acceptable (Jarvenpass, 1999; Li et al., 2005). Moore and Benbasat's hit ratio reflects the percentage of items that were correctly sorted. Six operations management researchers (primarily doctoral students) served as judges and assigned each item to an operational capability construct, based on the definitions supplied. Cohen's kappa averaged .72 for the initial set of items, which implied good consistency. Two thirds of the experts assigned one item to the "wrong" construct, implying that it was not a good indicator for the intended construct. Consequently, it was removed from the measurement instrument, resulting in an average kappa of .77. There was also some inconsistency in classifying items related to the operational responsiveness and operational reconfiguration constructs. Three of the experts were asked to explain the rationale for their assignment of these items, which resulted in rephrasing the wording of the corresponding items. They were then asked to assign the reworded items, resulting in an average Cohen's kappa of .82 and an overall hit ratio of $90.83 \%$, indicating a high level of content validity.

In order to validate the scales for reliability and validity, a questionnaire was drafted based on the results of the $Q$-sort. After a pilot test with a sample of 15 managers, the final questionnaire was generated. The unit of analysis is a plant, because operational capabilities are embedded in operations processes, which can be more easily observed in a plant context. Therefore, we targeted operations managers working at the plant level, because they have the necessary knowledge for responding to the research questions. 
Table 3: Responses from home improvement products (HOMEIMP) and the association for operations management (APICS).

\begin{tabular}{lcc}
\hline & \multicolumn{2}{c}{ Number of Responses } \\
\cline { 2 - 3 } & HOMEIMP & APICS \\
\hline First round & 22 & 103 \\
Second round & 25 & 57 \\
Third round & 15 & - \\
Total responses & 62 & 160 \\
Response rate & $30.0 \%$ & $6.15 \%$ \\
\hline
\end{tabular}

\section{Data Collection}

Data were collected from two sources: (i) a large manufacturer of home improvement products, which we refer to as HOMEIMP, and (ii) a professional organization dealing primarily with operations management issues. These two sources were treated as separate samples that completed the same survey form. The HOMEIMP sample consisted of managers working for a Fortune 100 multinational firm that was engaged in manufacturing home improvement products. HOMEIMP has a well developed and successful operations planning and execution system committed to quality and operational excellence, and its management recognizes the strategic importance of operational capabilities. It has over 30 major manufacturing divisions, thus, its managers are exposed to a wide variety of business environments. HOMEIMP provided the research team with an e-mail list of 207 managers. The second source of respondents was supplied by APICS: The Association for Operations Management. This professional society targets the types of managers that are the focus of this study. APICS granted access to its members through a link in its semimonthly e-newsletter. Various tactics were implemented to increase the response rate in both samples (Frohlich, 2002). External support for the study and requests for participation were obtained from the management of HOMEIMIP and APICS. Several types of incentives, including a lottery and the receipt of an executive summary of the results, were also used, as well as multiple waves of contact with the HOMEIMP managers. APICS put the survey announcement in its e-newsletter, then posted a reminder two weeks later.

The primary vehicle for survey administration was an online survey, an approach that has been noted for its response speed (Sheehan \& McMillian, 1999), lower cost (Weible \& Wallance, 1998), and improved quality of responses (Paolo, Bonaminio, Gibson, Patridge, \& Kallail, 2000). Complementing this was a downloadable hard copy. Table 3 contains a descriptive summary of respondent characteristics. Overall, we received 62 responses from the HOMEIMP sample and 160 from the APICS sample, representing a response rate of 30\% and 6.15\% (based on the number of members whose primary responsibility is operations), respectively. Although the APICS response rate was relatively low, it is consistent with other 
large-scale survey response rates, which are often in the 5\% to $10 \%$ range (Roth \& Van Der Velda, 1991; Stock, Greis, \& Kasarda, 2000; Shah \& Ward, 2003). Eight of the HOMEIMP and 20 of the APICS responses were discarded due to their high proportion of missing values. Nonresponse bias was assessed through comparisons of early and late respondents on the operational capability measures (Armstrong \& Overton, 1977). There was not a statistically significant difference on any of the items. Responses in the APICS sample came from a range of industries, including food/beverage, machinery, computer/electronic products, chemi$\mathrm{cal} /$ pharmaceutical products, electronic equipment, and transportation equipment.

\section{Assessment of Construct Validity}

Construct validity was evaluated in terms of unidimensionality, convergent validity, reliability, discriminant validity, and predictive (nomological) validity (Venkatraman, 1989; O’Leary-Kelly \& Vokurka, 1998; Li et al., 2005; Menor \& Roth, 2007; Shah \& Ward, 2007). The HOMEIMP data were used to test the construct validity of the initial instrument and modify it through item elimination; the refined instrument was then verified using the APICS data.

\section{Unidimensionality and convergent validity}

Unidimensionality refers to the existence of a single construct underlying a set of measures (Anderson, Gerbing, \& Hunter, 1987), whereas convergent validity is an assessment of consistency in measurement across multiple operationalizations (Venkatraman, 1989). We used confirmatory factor analysis (CFA) because it simultaneously tests the unidimensionality of a set of correlated latent constructs (O'Leary-Kelly \& Vokurka, 1998), which helps to establish both unidimensionality and convergent validity. In addition, CFA contains tests for improving the fit of the measurement model, which can be used to modify the measures, as we did based on the initial HOMEIMP results. The results of the CFA and the structural equation modeling (SEM) analysis were evaluated using a number of indices (Sila \& Ebrahimpour, 2005). Comparative fit index (CFI), nonnormed fit index (NNFI), and incremental fit index (IFI) values of .90 or above (Bentler \& Bonett, 1980; Bentler, 1992; Bendoly, Citurs, \& Konsynski, 2007) and root mean square error of approximation (RMSEA) less than or equal to .08 (Hu \& Bentler, $1999)$ indicate adequate model fit. The $p$-value associated with a given $\chi^{2}$ indicates whether the hypothesized model is supported, and $p>.10$ is generally considered satisfactory (Lawley \& Maxwell, 1971). The measurement instrument using the HOMEIMP data were modified based on the Lagrange multiplier test, which suggested improving overall fit indices by adding additional linkages between the items and constructs. The item that could improve the fit the most in each iteration was removed, because the addition of linkages implies that those items cross-load on multiple constructs. The CFA was then reconducted (Joreskog \& Sorbom, 1989). This iterative process was repeated until all model parameters and fit indices met the recommended thresholds; five items were ultimately removed. Bootstrapping was used to estimate the sampling distribution of the estimates by resampling from the original sample with replacement. Table 4 indicates that the final CFA had a good level of fit, with NNFI $=.95$, IFI $=.96$, 


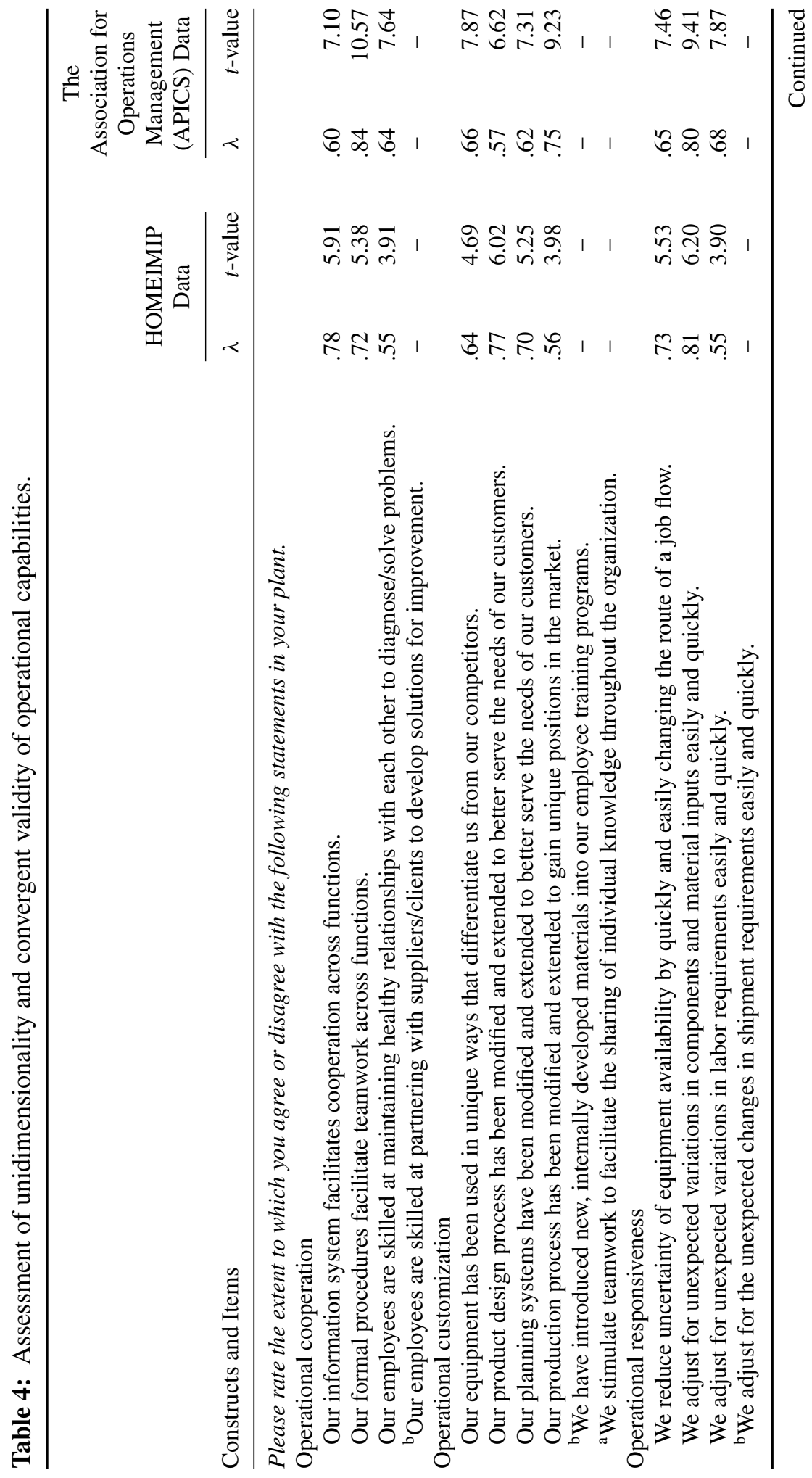




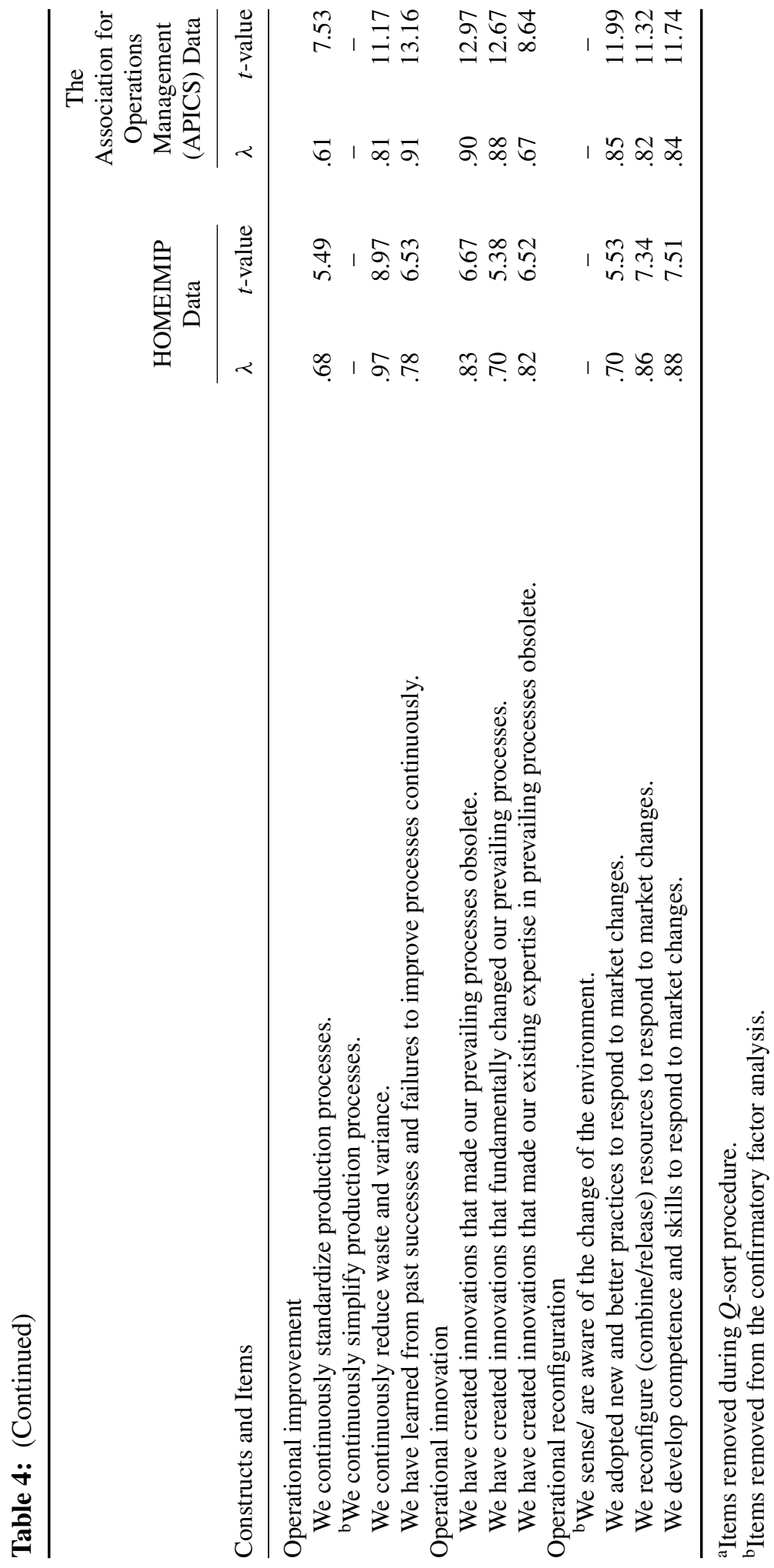


Table 5: Assessment of reliability.

\begin{tabular}{lccccccc}
\hline & & \multicolumn{2}{c}{$\begin{array}{c}\text { Home Improvement } \\
\text { Products } \\
\text { Construct }\end{array}$} & & \multicolumn{2}{c}{$\begin{array}{c}\text { The Association for } \\
\text { Operations } \\
\text { Management } \\
\text { (APICS) Data }\end{array}$} \\
\hline Operational cooperation & 3 & .76 & .73 & .73 & .74 \\
Operational customization & 4 & .76 & .77 & .74 & .75 \\
Operational responsiveness & 3 & .73 & .75 & .74 & .75 \\
Operational improvement & 3 & .84 & .85 & .81 & .82 \\
Operational innovation & 3 & .82 & .82 & .85 & .86 \\
Operational reconfiguration & 3 & .85 & .86 & .87 & .87 \\
Cost performance & 3 & - & - & .88 & .88 \\
Quality performance & 5 & - & - & .94 & .94 \\
Delivery performance & 4 & - & - & .83 & .89 \\
Flexibility performance & 2 & - & - & .76 & .78 \\
\hline
\end{tabular}

CFI $=.96$, RMSEA $=.05$ and $\chi^{2}=153.56$ with $d f=137(p<.16)$. All the standardized factor loadings were above .55 and were significant at $p<.01$. These findings provide empirical evidence of unidimensionality and convergent validity.

\section{Reliability}

Although Cronbach's $\alpha$ is based on the assumption that all indicators are equally important in measuring the latent construct (Venkatraman, 1989; Li et al., 2005), composite measure reliability $\left(\rho_{c}\right)$ captures the proportion of measure variance attributable to the latent variable (Werts, Linn, \& Joreskog, 1974). A $\rho_{c}$ greater than .50 implies that the variance extracted by the latent construct is more than that extracted by the error term (Bagozzi, 1981). Both reliability measures are reported in Table 5. All the Cronbach's $\alpha$ and $\rho_{c}$ indices were greater than .73, thus all construct measures were reliable.

\section{Discriminant validity}

Discriminant validity was assessed using two-factor CFA models that related each possible pair of constructs, with the correlation between the two constructs first set freely and then constrained to one (Venkatraman, 1989; Bagozzi, Yi, \& Phillips, 1991; Sethi \& King, 1994; Li et al., 2005). The $\chi^{2}$ value for the unconstrained model was significantly lower than that of the constrained model in all cases, establishing discriminant validity among all the constructs (Joreskog, 1971). All the $\chi^{2}$ differences were significant at $p<.01$, indicating strong support for the discriminant validity of the constructs (see Table 6). We also verified discriminant validity by comparing the average variance extracted (AVE) for each pair of constructs with the squared correlation between the two constructs (Fornell \& Laker, 1981). In all cases, the AVE was greater than the squared correlation, thus, each construct itself had more internal variance than the variance shared between constructs. 


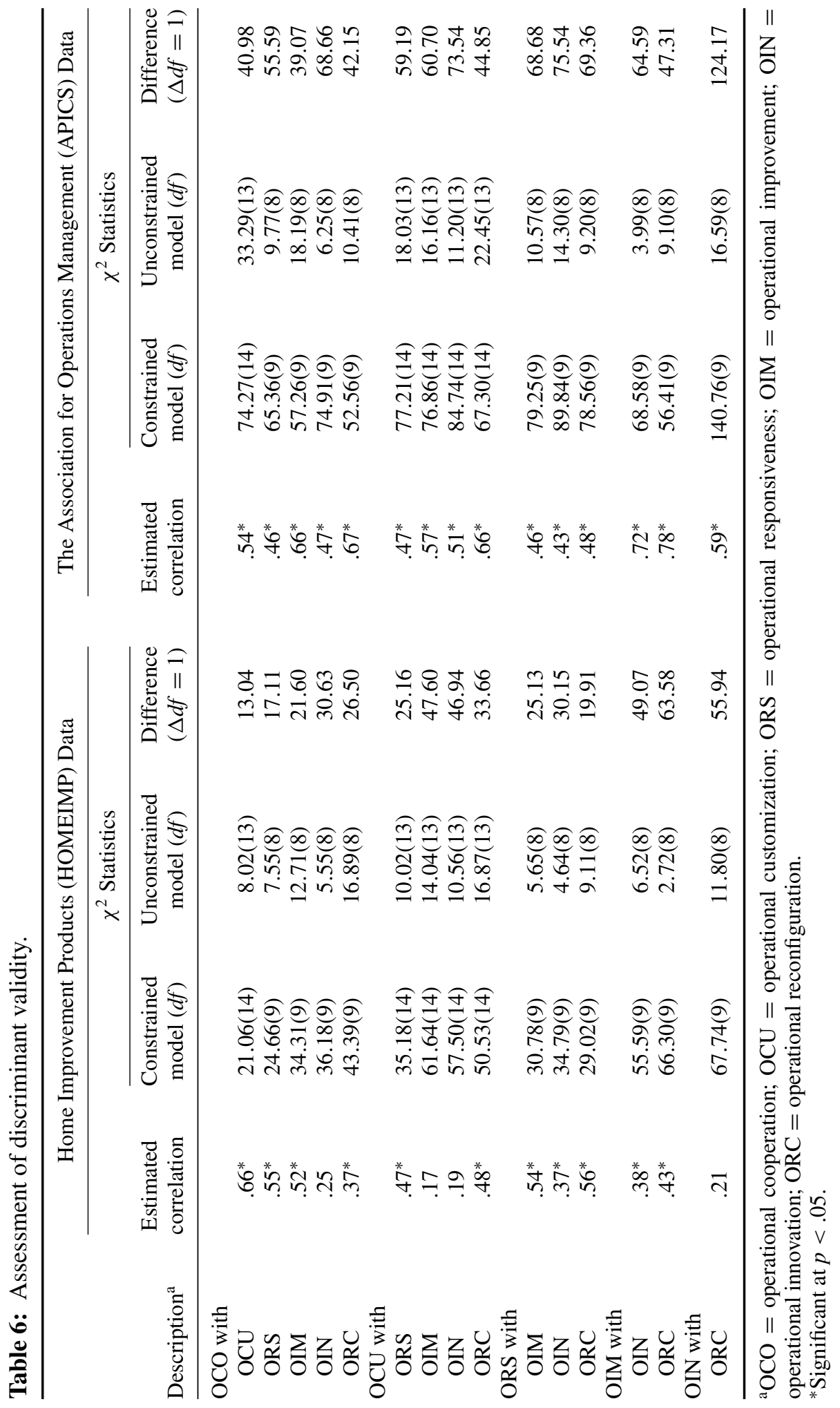




\section{Replication}

A single study cannot provide "valid" measures, even when it employs a rigorous process of analysis and refinement, and confidence in a measurement instrument can only be obtained through replication (Venkatraman, 1989). Therefore, we repeated the analysis of the modified measurement instrument using the responses from the APICS respondents. The results are summarized in Tables 4-6, providing greater confidence in using these newly developed scales in future research.

\section{Predictive validity}

We assessed predictive validity using APICS sample. Predictive validity is important because the conceptual meaning of a construct not only depends on its conceptualization but also on its relationship with other variables (Bagozzi \& Fornell, 1982); it is verified by a significant association between the scales and an independent measure of the relevant criterion (Nunnally, 1978). According to $\mathrm{RBV}$, operational capabilities can contribute to competitive advantage (they are one of the necessary conditions to create competitive advantage, but not the only one). Operational capabilities are particularly desirable in generating positive intermediate outcomes, in terms of the way that a firm carries out an action or a series of actions. The HOMEIMP dataset contained multiple respondents from the same division; however, we were not able to verify whether they came from the same plant. To be conservative, we used only the APICS sample to test predictive validity, to avoid potentially biased results.

The predominant approach in the literature is to use cost, quality, delivery, and flexibility as the dimensions of overall operations performance (Miller \& Roth, 1994; Ward, Duray, Leong, \& Sum, 1995; Cua et al., 2001; Schroeder et al., 2002). Details of the test results for unidimensionality and convergent validity and reliability are reported in Tables 5 and 7. Predictive validity was assessed by the parameter estimates $(\gamma)$ between the operational capabilities and dimensions of operations performance. A group of SEMs was specified and tested, where the antecedent variables were the six operational capabilities, and the outcome variables were the four performance dimensions. Table 8 reports the standardized coefficients of the $\gamma$ - and $t$-values, revealing that 22 out of the 24 tests had significant positive results, providing evidence of predictive validity. That is, operational capabilities are not an isolated factor in an operations system; rather they are one of the critical factors and may intertwine with other factors to impact performance outcomes.

\section{DISCUSSION}

In reviewing the results, two key points are discussed: the notion of operational capabilities as the secret ingredient, and the measurement of constructs, such as operational capabilities, that are difficult to observe directly.

\section{Operational Capabilities: The Secret Ingredient}

This study provided a rationale for viewing operational capabilities as critical to success at both the operations and corporate levels. We have referred to them as the secret ingredient because, like the purloined letter of Edgar Allen Poe 
Table 7: Assessment of unidimensionality and convergent validity of operations performance. $^{\text {a }}$

\begin{tabular}{|c|c|c|}
\hline \multirow[b]{2}{*}{ Constructs and Items } & \multicolumn{2}{|c|}{$\begin{array}{l}\text { The Association for } \\
\text { Operations Management } \\
\text { (APICS) Data }\end{array}$} \\
\hline & $\begin{array}{l}\text { Standardized } \\
\text { coefficient }\end{array}$ & $t$-value \\
\hline \multicolumn{3}{|c|}{$\begin{array}{l}\text { Relative to your competition, how would you rate the performance of your plant operation } \\
\text { on the following dimensions of performance? }\end{array}$} \\
\hline \multicolumn{3}{|l|}{ Cost } \\
\hline Manufacturing unit cost & .81 & 11.14 \\
\hline Manufacturing overhead cost & .82 & 11.34 \\
\hline Total cost (acquisition, setup, maintenance, service, etc.) & .91 & 13.07 \\
\hline \multicolumn{3}{|l|}{ Quality } \\
\hline Product conformance & .87 & 12.92 \\
\hline Product durability & .86 & 12.52 \\
\hline Product overall quality & .94 & 14.57 \\
\hline Product reliability & .95 & 15.05 \\
\hline Product features & .80 & 11.19 \\
\hline \multicolumn{3}{|l|}{ Delivery } \\
\hline Delivery accuracy & .79 & 10.18 \\
\hline Delivery dependability & .74 & 9.93 \\
\hline Delivery quality & .83 & 10.78 \\
\hline \multicolumn{3}{|l|}{ Flexibility } \\
\hline Ability to adjust product volume & .70 & 8.00 \\
\hline Ability to produce a range of products & .88 & 9.76 \\
\hline
\end{tabular}

${ }^{a}$ Model fit indices (based on APICS data): NNFI $=.93$, IFI $=.95$, CFI $=.94$, RMSEA $=.09$ and $\chi^{2}=130.50$ with $d f=59(p<.01)$. All the factor loadings are significant at $p<.01$.

(2002), operational capabilities are essentially "hidden in plain view." That is, operational capabilities exist but are overlooked by both the managers who work with them and researchers. They are taken for granted and fail to generate attention because they do not seem unusual. This is due to the very nature of operational capabilities: they are tightly embedded in the organizational fabric of the operations management system. This embeddedness is the result of the interconnectness of operational capabilities with resources and operational practices, linkages between operations capabilities and the social network, and the fit with the primary problems that the firm and its operations management address. This embeddedness makes operational capabilities tacit in nature and path dependent, which creates a barrier to imitation (Grewal \& Slotegraaf, 2007). As a result, operational capabilities are crucial in understanding and explaining performance variability. Thus, although resources and operational practices are important, they are not sufficient.

Operational capabilities are the secret ingredient that is hidden in plain view for several reasons. First, operational capabilities are not as obvious and tangible 
Table 8: Assessment of predictive validity. ${ }^{\text {a }}$

\begin{tabular}{|c|c|c|c|c|c|c|c|c|}
\hline \multirow{2}{*}{$\begin{array}{l}\text { The Association for } \\
\text { Operations } \\
\text { Management } \\
\text { (APICS) Data }\end{array}$} & \multicolumn{2}{|c|}{ Cost } & \multicolumn{2}{|c|}{ Quality } & \multicolumn{2}{|c|}{ Delivery } & \multicolumn{2}{|c|}{ Flexibility } \\
\hline & $\gamma$ & $t$-value & $\gamma$ & $t$-value & $\gamma$ & $t$-value & $\gamma$ & $t$-value \\
\hline $\begin{array}{l}\text { Operational } \\
\text { cooperation }\end{array}$ & .28 & $2.69^{*}$ & .21 & $2.10^{*}$ & .29 & $2.70^{*}$ & .27 & $2.77^{*}$ \\
\hline $\begin{array}{l}\text { Operational } \\
\text { customization }\end{array}$ & .45 & $4.08^{*}$ & .32 & $3.17^{*}$ & .36 & $3.27^{*}$ & .44 & $3.32^{*}$ \\
\hline $\begin{array}{l}\text { Operational } \\
\text { responsiveness }\end{array}$ & .35 & $3.18^{*}$ & .30 & $2.90^{*}$ & .39 & $3.42^{*}$ & .49 & $4.62^{*}$ \\
\hline $\begin{array}{l}\text { Operational } \\
\text { improvement }\end{array}$ & .36 & $3.45^{*}$ & .09 & .92 & .29 & $2.74^{*}$ & .20 & $2.07^{*}$ \\
\hline $\begin{array}{l}\text { Operational } \\
\text { innovation }\end{array}$ & .35 & $3.68^{*}$ & .14 & 1.52 & .20 & $2.06^{*}$ & .27 & $2.63^{*}$ \\
\hline $\begin{array}{l}\text { Operational } \\
\text { reconfiguration }\end{array}$ & .54 & $5.63^{*}$ & .28 & $3.00^{*}$ & .37 & $3.69^{*}$ & .46 & $4.72^{*}$ \\
\hline
\end{tabular}

a Predictive validity was assessed only in the APICS sample.

${ }^{*}$ Significant at $p<.05$.

as operational practices and resources. When trying to explain success, managers tend to focus on factors that are readily perceived and relatively easy to duplicate and implement. This is what Spear and Bowen (1999) and Spear (2004) observed when describing how others viewed the success of Toyota. Although observers saw Toyota using general purpose equipment, statistical process control, and crossfunctional employees, what they did not as readily observe was how Toyota had extended and customized all of these elements to address its specific problems. They did not see Toyota's "DNA" (Spear \& Bowen, 1999). A critical element of this DNA is Toyota's operational capabilities. Using this perspective, it is evident why even the most detailed and precise duplication efforts (efforts where a firm deployed exactly the same practices as Toyota) could not achieve the same level of performance. The resources and practices that worked so well at Toyota might not fit the implementing organization's culture or history or may not even be consistent with the problem that the firm was interested in solving. These elements (ensuring that the resources and practices fit the organization's history and with the problem being solved) are central attributes of operational capabilities. This observation is also supported by research reported by Westphal, Gulati, and Shortell (1997). When studying corporate experiences with TQM, they found that the high performers understood, expanded, and tailored TQM and its specific practices to their unique needs, resource profiles, and interfirm relationships. In contrast, the lower performers blindly imitated techniques and tools without any modification or adjustment. A similar explanation is provided by Wheelwright and Hayes's (1985) four stages. Stage II firms (externally neutral) strive to improve through extensive and indiscriminant imitation of competitors. In contrast, Stage III firms are more 
successful in their improvement efforts by screening potential new resources and practices for consistency with their operations strategy.

Second, operational capabilities are closely linked to resources and operational practices. This interconnectedness makes operational capabilities difficult to identify separately, and consequently, their existence may be overlooked. There is a tendency for both managers and researchers to confuse resource and operational practices with operational capabilities. For example, Eisenhardt and Martin (2000) and Lee and Kelley (2008) have noted that "best practices" can be viewed as a type of capability. Yet, Teece (2007) disagreed with this position, stating that, under certain conditions, best practices are not capabilities, nor does their use lead to a sustainable competitive advantage. This position was repeated by Hayes, Pisano, Upton, and Wheelwright (2005). This confusion is not surprising given the close linkages that exist between operational capabilities, resources, and operational practices.

Third, the development of operational capabilities is associated with the culture and history of a particular firm and the specific problems that it is striving to solve. There are two types of fit related to operational capabilities: fit with organizational culture and history, and fit with the specific problem being addressed. Toyota's operational capabilities were built to solve its primary problem: given its production lines, how could it be flexible enough to change product mix to accommodate changing demand (Womack, Jones, \& Roos, 1990)? Although GM spent a great deal of time and money studying Toyota's success, it did not appreciate that GM and Toyota were solving fundamentally different problems. To GM, the fundamental problem was reducing cost, producing the most with a given level of resources. In contrast, Toyota was more interested in improving flexibility, minimizing the level of resources needed to satisfy a given level of demand. Unfortunately, managers from one firm, when studying another, tend to view activities through a lens built on the assumption that the firm being studied is solving the same type of problem(s) that the observers are. This myopia prevents them from seeing and assessing operational capabilities.

\section{Measurement of Operational Capabilities}

A major contribution of this study is that it conceptually develops and empirically evaluates a set of multi-item measurement scales for operational capabilities. As previously noted, operational capabilities are tacit and distinctive in their details and in the ways they develop. As a result, they tend to be overlooked, and there has been little effort devoted to measure them. While recognizing the difficulties in measuring operational capabilities directly, we argue that it is still possible to empirically and operationally measure them by focusing on commonalities across firms and on certain reflective indicators. Given the importance of operational capabilities, our measurement scales offer the potential for several promising insights.

First, our work enables researchers to identify and assess operational capabilities and their impact on organizational success, controlling for the presence of operational practices. Second, our approach facilitates research on relationships among operational capabilities, whether it is effective to develop those capabilities 
simultaneously or focus on a specific capability. Third, with this instrument, we are able to examine the kinds of operational practices that support the development of a specific operational capability. Finally, this study helps to address an important question that has long plagued operations strategy researchers, who have focused on commonalities when studying how operations can be used to enhance the organizational capabilities. This has led them to examine research topics involving operational practices and competitive priorities (Sakakibara, Flynn, Schroeder, \& Morris, 1997; Kotha \& Swamidass, 2000; Ward \& Duray, 2000; Cua et al., 2001; Boyer \& Lewis, 2002). Yet, in focusing on these commonalities, they have overlooked the impact and importance of differentiation. For many strategic management researchers, the key to success does not lie in commonalities, but rather in the differences between firms. In fact, this notion of differences is what underlies the concept of equifinality (Hambrick, 1984). Although operational practices promote commonality, it is operational capabilities, which are firm and problem specific, that account for some of the inherent differences between firms. In other words, strategic planning merges elements that contribute to commonality with elements that contribute to differentiation in such a way as to produce a unique solution to the needs of its critical customers. Through focusing on operational capabilities, we can see that differentiation is inherent to every firm and to every operations management system. By providing a methodology for studying and assessing operational capabilities, this study enhances the ability of researchers to view operations strategy from a richer perspective.

\section{CONCLUDING COMMENTS}

Much of the thinking about operations strategy, and in strategic management in general, revolves around three critical elements: operational capabilities, operational practices, and resources. There is a tendency for researchers to confuse them because they are very closely interrelated. However, they are separate and distinct constructs. By focusing on operational capabilities, we make three substantive achievements in this study.

First, we propose a conceptual definition of operational capabilities and an illustration which captures their essential traits. These traits help us differentiate operational capabilities from operational practices and resources and understand the process by which competitive advantage is developed. Second, we provide a framework of operational capabilities that covers six salient dimensions. We develop measures of operational capabilities and validate them using a two-stage approach. The empirically validated measurement instrument allows researchers to conduct survey research to assess the impact of operational capabilities on performance. Lastly, the concept of operational capabilities and the measurement instrument form a foundation for improved theoretical understanding of dynamic capabilities and their development process, which are imperative in today's dynamic and turbulent environment.

A strength of this study is that we use two separate datasets to validate the measurement instrument. At the same time, we acknowledge the limitations of the low response rate for the APICS data. Although the psychometric properties of the measurement instrument indicate strong evidence of reliability and validity, the 
low APICS response rate could still threaten the validity of the results. However, inclusion of the HOMEIMP sample helps to counteract this threat. In addition, we rely on sole respondents, thus, the accuracy of the responses could be improved if measures of predictors and criterion variables were obtained from different sources. Such data can generate more accurate estimates of predictive validity. In addition, the generalizability of our results is limited to the specific samples; however, it is noteworthy that there was substantial agreement in the findings using the two samples. Finally, although we identified the operational capabilities taxonomy primarily in a manufacturing context, we believe that it can be extended to the service operations environment. The validated instrument from this study serves as a good starting point to extend it to the service context with further refinement. [Received: April 2009. Accepted: May 2010]

\section{REFERENCES}

Amit, R., \& Schoemaker, P. J. H. (1993). Strategic assets and organizational rent. Strategic Management Journal, 14(1), 33-46.

Amundson, S. (1998). Relationships between theory-driven empirical research in operations management and other disciplines. Journal of Operations Management, 16(4), 341-350.

Anand, G., Ward, P., Tatikonda, M., \& Schilling, D. (2009). Dynamic capabilities through continuous improvement infrastructure. Journal of Operations Management, 27(6), 444-461.

Anderson, J. C., Gerbing, D. W., \& Hunter, J. E. (1987). On the assessment of unidimensional measurement: Internal and external consistency, and overall consistency criteria. Journal of Marketing Research, 24(4), 432-437.

Anderson, D., \& Narus, J. (1998). Business marketing: Understand what customers value. Harvard Business Review, 76(3), 53-61.

Armstrong, S., \& Overton, T. (1977). Estimating nonresponse bias in mail surveys. Journal of Marketing Research, 14(3), 396-402.

Bagozzi, R. P. (1981). An examination of the validity of two models of attitude. Multivariate Behavioral Research, 16(3), 323-359.

Bagozzi, R. P., \& Fornell, C. (1982). Theoretical concepts, measurements, and meaning. In C. Fornell (Ed.), A second generation multivariate analysis (pp. 24-38). New York: Praeger.

Bagozzi, R. P., Yi, Y., \& Phillips, L. M. (1991). Assessing construct validity in organizational research. Administrative Science Quarterly, 36(3), 421-458.

Barney, J. B. (1991). Firm resources and sustained competitive advantage. Journal of Management, 17(1), 99-120.

Barney, J. B. (1995). Looking inside for competitive advantage. Academy of Management Executive, 9(4), 49-61.

Bendoly, E., Citurs, A., \& Konsynski, B. (2007). Internal infrastructural impacts on RFID perceptions and commitment: Knowledge, operational procedures, and information-processing standards. Decision Sciences, 38(3), 423-449. 
Benner, M. M., \& Tushman, M. L. (2003). Exploitation, exploration, and process management: The productivity dilemma revisited. Academy of Management Review, 28(2), 238-256.

Bentler, P. (1992). On the fit of models to covariances and methodology to the Bulletin. Psychological Bulletin, 112(3), 400-404.

Bentler, P. M., \& Bonett, D. G. (1980). Significance tests and goodness of fit in the analysis of covariance structures. Psychological Bulletin, 88(3), 588-606.

Boyer, K. K., \& Lewis, M. W. (2002). Competitive priorities: Investigating the need for trade-offs in operations strategy. Production and Operations Management, 11(1), 9-20.

Bozarth, C., Warsing, D., Flynn, B., \& Flynn, E. (2009). The impact of supply chain complexity on manufacturing plant performance. Journal of Operations Management, 27(1), 78-93.

Cagliani, R., Acur, N., \& Boer, H. (2006). Patterns of change in manufacturing strategy configuration. International Journal of Operations and Production Management, 25(7), 701-718.

Cavusgil, E., Seggie, S. H., \& Talay, M. B. (2007). Dynamic capabilities view: Foundations and research agenda. Journal of Marketing Theory and Practice, 15(2), 159-166.

Churchill, G. A. (1979). A paradigm for developing better measures of marketing constructs. Journal of Marketing Research, 16(1), 12-27.

Coates, T. T., \& McDermott, C. M. (2002). An exploratory analysis of new competencies: A resource based view perspective. Journal of Operations Management, 20(5), 435-450.

Cohen, J. (1960). A coefficient of agreement for nominal scales. Educational and Psychological Measurement, 20(1), 37-46.

Colotta, I., Shi, Y., \& Gregory, M. (2003). Operation and performance of international manufacturing networks. International Journal of Operations and Production Management, 23(10), 1184-1206.

Cua, K. O., McKone, K. E., \& Schroeder, R. G. (2001). Relationship between implementation of TQM, JIT, and TPM and manufacturing performance. Journal of Operations Management, 19(6), 675-694.

Dierickx, I., \& Cool, K. (1989). Asset stock accumulation and sustainability of competitive advantage. Management Science, 35(12), 1504-1511.

Dosi, G., Hobday, M., \& Marengo, L. (2003). Problem-solving behavior, organizational forms, and the complexity of tasks. In C. E. Helfat (Ed.), The SMS Blackwell handbook of organizational capabilities (pp. 167-192). Malden, MA: Blackwell.

Dosi, G., Nelson, R. R., \& Winter, S. G. (2000). Introduction: The nature and dynamics of organizational capabilities. In G. Dosi, R. R. Nelson, \& S. G. Winter (Eds.), The nature and dynamics of organizational capabilities (pp. 1-22). New York: Oxford University Press. 
Droge, C., Jayaram, J., \& Vickery, S. (2004). The effects of internal versus external integration practices on time-based performance and overall firm performance. Journal of Operations Management, 22(6), 557-573.

Eisenhardt, K. M., \& Martin, J. A. (2000). Dynamic capabilities: What are they? Strategic Management Journal, 21(10-11), 1105-1121.

Escrig-Tena, A. B., \& Bou-Llusar, J. C. (2005). A model for evaluating organizational competencies: An application in the context of a quality management initiative. Decision Sciences, 36(2), 221-257.

Fleiss, J. (1981). Statistical methods for rates and proportions (2nd ed.). New York: Wiley.

Flynn, B., \& Flynn, E. (1999). Information-processing alternative for coping with manufacturing environment complexity. Decision Sciences, 30(4), 10211052.

Flynn, B. B., Sakakibara, S., \& Schroeder, R. G. (1995). Relationship between JIT and TQM: Practices and performance. Academy of Management Journal, $38(5), 1325-1360$.

Fornell, C., \& Laker, D. F. (1981). Evaluating structural equation models with unobservable variables and measurement errors. Journal of Marketing Research, 18(1), 39-50.

Frohlich, M. T. (2002). Techniques for improving response rates in OM survey research. Journal of Operations Management, 20(1), 53-62.

Galbraith, J. (1973). Organizational design. Reading, MA: Addison-Wesley.

Galbraith, J. (1979). Organizing for the future: The new logic for managing complex organizations. San Francisco: Jossey-Bass.

Gonzalez-Benito, J. (2007). A theory of purchasing's contribution to business performance. Journal of Operations Management, 25(4), 901-917.

Grant, R. M. (1991). The resource-based theory of competitive advantage: Implications for strategy formulation. California Management Review, 33(3), $114-135$.

Grant, R. (1996). Toward a knowledge-based theory of the firm. Strategic Management Journal, 17(9), 109-122.

Grewal, R., \& Slotegraaf, R. J. (2007). Embeddedness of organizational capabilities. Decision Sciences, 38(3), 451-488.

Größler, A., \& Grübner, A. (2006). An empirical model of the relationships between manufacturing capabilities. International Journal of Operations \& Production Management, 26(5), 458-485.

Gupta, A., \& Whitehouse, F. R. (2001). Firms using advanced manufacturing technology management: An empirical analysis based on size. Integrated Manufacturing Systems, 12(5), 346-350.

Hambrick, D. C. (1984). Taxonomic approaches to studying strategy: Some conceptual and methodological issues. Journal of Management, 10(1), 27-41. 
Harreld, J. B., O’Reilly, C. A., \& Tushman, M. L. (2007). Dynamic capabilities at IBM: Driving strategy into action. California Management Review, 49(4), 21-43.

Harrington, H., \& Mathias, D. (1997). ISO9000 and beyond: From compliance to performance improvement. New York: McGraw-Hill.

Hayes, R. H., Pisano, G. P., Upton, D. M., \& Wheelwright, S. C. (2005). Operations, strategy, and technology: Pursuing the competitive edge. Hoboken, NJ: Wiley.

Hofer, C. W., \& Schendel, D. (1978). Strategy formulation: Analytical concepts. St. Paul, MN: West Publishing.

Holweg, M., \& Pil, F. (2008). Theoretical perspectives on the coordination of supply chains. Journal of Operations Management, 26(3), 389-406.

Hu, L., \& Bentler, P. (1999). Cutoff criteria for fit indexes in covariance structure analysis: Conventional criteria versus new alternatives. Structural Equation Modeling, 6(1), 1-55.

Jarvenpass, S. (1999). The effect of task demand and graphical format on information process strategies. Management Science, 21(5), 285-303.

Jarvis, C. B., Mackenzie, S. B., \& Podsakoff, P. M. (2003). A critical review of construct indicators and measurement model misspecification in marketing and consumer research. Journal of Consumer Research, 30(2), 199-218.

Joreskog, K. G. (1971). Statistical analysis of congeneric tests. Psychometrika, 36(2), 109-133.

Joreskog, K. G., \& Sorbom, D. (1989). LISREL 7 users' reference guide. Chicago: Scientific Software.

Kim, S. (2006). The effect of supply chain integration on the alignment between corporate competitive capability and supply chain operational capability. International Journal of Operations and Production Management, 25(10), 1084-1107.

Kotha, S., \& Swamidass, P. M. (2000). Strategy, advanced manufacturing technology and performance: Empirical evidence from U. S. manufacturing firms. Journal of Operations Management, 18(3), 257-277.

Koufteros, X., Cheng, T., \& Lai, K. (2007). "Black box" and "gray box" for supplier integration in product development: Antecedents, consequences and the moderating role of firm size. Journal of Operations Management, 25(4), 847-870.

Koufteros, X., Vonderembase, M., \& Doll, W. (2002). Integrated product development practices and competitive capabilities: The effects of uncertainty, equivocality and platform strategy. Journal of Operations Management, 20(4), 331-355.

Landry, J. (1998). Supply chain management: The case for alliances. Harvard Business Review, 76(6), 24-25.

Lawley, D. N., \& Maxwell, A. E. (1971). Factor analysis as a statistical method. London: Butterworth. 
Lee, H., \& Kelley, D. (2008). Building dynamic capabilities for innovation: An exploratory study of key management practices. $R \& D$ Management, 38(2), $155-168$.

Leonard-Barron, D. (1992). Core capabilities and core rigidities: A paradox in managing new product development. Strategic Management Journal, 13(2), $111-125$.

Li, S., Rao, S. S., Ragu-Nathan, T. S., \& Ragu-Nathan, B. (2005). Development and validation of a measurement instrument for studying supply chain management practices. Journal of Operations Management, 23(6), 618-641.

Little, T. D., Lindenberger, U., \& Nesselroade, J. R. (1999). On selecting indicators for multivariate measurement and modeling with latent variables: When "good" indicators are bad and "bad" indicators are good. Psychological Methods, 4(2), 192-211.

Martinez Sanchez, A., \& Perez Perez, M. (2005). Supply chain flexibility and firm performance: a conceptual model and empirical study in the automotive industry. International Journal of Operations and Production Management, 25(7), 680-700.

McKeown, B., \& Thomas, D. (1988). Q methodology. Beverly Hills, CA: Sage.

Menor, L. J., \& Roth, A. V. (2007). New service development competence in retail banking: Construct development and measurement validation. Journal of Operations Management, 25(4), 825-846.

Miller, J. G., \& Roth, A. (1994). A taxonomy of manufacturing strategies. Management Science, 40(3), 285-304.

Moore, G. C., \& Benbasat, I. (1991). Development of an instrument to measure the perceptions of adopting an information technology innovation. Information System Research, 2(2), 192-222.

Mosey, S. (2005). Understanding new-to-market product development in SMEs. International Journal of Operations and Production Management, 25(2), 114-130.

Mukherjee, A., Lapré, M., \& Van Wasenhove, L. (1998). Knowledge driven quality improvement. Management Science, 44, S35-S49.

Narasimhan, R., Swink, M., \& Kim, S. W. (2005). An exploratory study of manufacturing practice and performance interrelationships: Implications for capability progression. International Journal of Operations \& Production Management, 25(9/10), 1013-1033.

Narasimhan, R., \& Talluri, S. (2009). Perspectives on risk management in supply chains. Journal of Operations Management, 27(2), 114-118.

Nunnally, J. C. (1978). Psychometric theory (2nd ed.). New York: McGraw-Hill.

O'Leary-Kelly, S. W., \& Vokurka, R. J. (1998). The empirical assessment of construct validity. Journal of Operations Management, 16(4), 387-405.

Ordanini, A., \& Rubera, G. (2008). Strategic capabilities and internet resources in procurement: A resource-based view of B-to-B buying processes. International Journal of Operations and Production Management, 28(1), 27-52. 
Pandza, K., Horsburgh, S., Gorton, K., \& Polajnar, A. (2003a). A real options approach to managing resources and capabilities. International Journal of Operations and Production Management, 23(9), 1010-1036.

Pandza, K., Polajnar, A., Buchmeister, B., \& Thorpe, R. (2003b). Evolutionary perspectives on the capabilities accumulation process. International Journal of Operations and Production Management, 23(7/8), 822-849.

Paolo, A. M., Bonaminio, G. A., Gibson, C., Patridge, T., \& Kallail, K. (2000). Response rate comparisons of e-mail- and mail-distributed student evaluations. Teaching and Learning in Medicine, 12(2), 81-84.

Peng, D. X., Schroeder, R. G., \& Shah, R. (2008). Linking routines to operations capabilities: A new perspective. Journal of Operations Management, 26(6), 730-748.

Penrose, E. (1959). The theory of the growth of the firm. New York: Wiley.

Peteraf, M. A. (1993). The cornerstones of competitive advantage. Strategic Management Journal, 14(3), 179-191.

Poe, E. (2002). The complete tales \& poems of Edgar Allen Poe. Edison, NJ: Castle Books.

Roth, A. V., \& Van Der Velda, M. (1991). Operations as marketing: A competitive service strategy. Journal of Operations Management, 10(3), 303-327.

Rothaermel, F. T., \& Hess, A. M. (2007). Building dynamic capabilities: Innovation driven by individual-, firm-, and network-level effects. Organizational Science, 18(6), 898-921.

Sakakibara, S., Flynn, B. B., Schroeder, R. G., \& Morris, W. T. (1997). The impact of Just-in-Time manufacturing and its infrastructure on manufacturing performance. Management Science, 43(9), 1246-1257.

Schein, E. H. (2004). Organizational culture and leadership. San Francisco: Jossey-Bass.

Schreyogg, G., \& Kliesch-Eberl, M. (2007). How dynamic can organizational capabilities be? Towards a dual-process model of capability dynamization. Strategic Management Journal, 28(9), 913-933.

Schroeder, R. G., Bates, K. A., \& Junttila, M. A. (2002). A resource-based view of manufacturing strategy and the relationship to manufacturing performance. Strategic Management Journal, 23(2), 105-117.

Sen, F. K., \& Egelhoff, W. G. (2000). Innovative capabilities of a firm and the use of technical alliances. IEEE Transactions on Engineering Management, 47(2), 174-183.

Sethi, V., \& King, W. R. (1994). Development of measures to assess the extent to which an information technology application provides competitive advantage. Management Science, 40(12), 1601-1627.

Shah, R., \& Ward, P. T. (2003). Lean manufacturing: Context, practice bundles, and performance. Journal of Operations Management, 21(2), 129-150.

Shah, R., \& Ward, P. T. (2007). Defining and developing measures of lean production. Journal of Operations Management, 25(4), 785-805. 
Sheehan, K. B., \& McMillian, S. J. (1999). Response variation in e-mail surveys: An exploration. Journal of Advertising Research, 39(4), 45-54.

Sila, I., \& Ebrahimpour, M. (2005). Critical linkages among TQM factors and business results. International Journal of Operations \& Production Management, 25(11), 1123-1155.

Sitkin, S., \& Stickel, D. (1996). The road to hell: The dynamics of distrust in an era of quality. In R. Kramer \& T. Tyler (Eds.), Trust in organizations: Frontiers of Theory and Research (pp. 196-215). Thousand Oaks, CA: Sage.

Spear, S. J. (2004). Learning to lead at Toyota. Harvard Business Review, 82(5), 78-86.

Spear, S. J., \& Bowen, H. K. (1999). Decoding the DNA of the Toyota production system. Harvard Business Review, 77(5), 96-106.

Stock, G. N., Greis, N. P., \& Kasarda, J. D. (2000). Enterprise logistics and supply chain structure. Journal of Operations Management, 18(5), 531-547.

Subramaniam, M., \& Youndt, M. A. (2005). The influence of intellectual capital on the types of innovative capabilities. Academy of Management Journal, 48(3), 450-463.

Swafford, P., Ghosh, J., \& Murthy, N. (2006). A framework for assessing value chain agility. International Journal of Operations and Production Management, 26(2), 118-140.

Swink, M., \& Hegarty, W. H. (1998). Core manufacturing capabilities and their links to product differentiation. International Journal of Operations and Production Management, 18(4), 374-396.

Swink, M., Narasimhan, R., \& Kim, S. W. (2005). Manufacturing practices and strategy integration: Effects on cost efficiency, flexibility, and market-based performance. Decision Sciences, 36(3), 427-457.

Teece, D. (2007). Explicating dynamic capabilities: The nature and microfoundations of (sustainable)enterprise performance. Strategic Management Journal, 28(13), 1319-1350.

Teece, D. J., Pisano, G., \& Shuen, A. (1997). Dynamic capabilities and strategic management. Strategic Management Journal, 18(7), 509-533.

Upton, D. (1994). The management of manufacturing flexibility. California Management Review, 36(1), 71-89.

Venkatraman, N. (1989). Strategic orientation of business enterprises: The construct, dimensionality and measurement. Management Science, 35(8), 942962.

Wang, C. L., \& Ahmed, P. K. (2007). Dynamic capabilities: A review and research agenda. International Journal of Management Reviews, 9(1), 31-51.

Ward, P. T., \& Duray, R. (2000). Manufacturing strategy in context: Environment, competitive strategy and manufacturing strategy. Journal of Operations Management, 18(2), 123-138. 
Ward, P. T., Duray, R., Leong, G. K., \& Sum, C. C. (1995). Business environment, operations strategy and performance: An empirical study of Singapore manufacturers. Journal of Operations Management, 13(1), 99-115.

Weible, R., \& Wallance, J. (1998). The impact of the Internet on data collection. Marketing Research, 10(1), 19-27.

Wernerfelt, B. (1984). A resource-based view of the firm. Strategic Management Journal, 5(2), 171-180.

Werts, C. E., Linn, R. L., \& Joreskog, K. G. (1974). Interclass reliability estimates: Testing structural assumptions. Educational and Psychological Measurement, 34(1), 25-33.

Westphal, J. D., Gulati, R., \& Shortell, S. M. (1997). Customization or conformity? An institutional and network perspective on the content and consequences of TQM adoption. Administrative Science Quarterly, 42(2), 366-394.

Wheelwright, S. C., \& Hayes, R. H. (1985). Competing through manufacturing. Harvard Business Review, 63(1), 99-109.

Winter, S. G. (2000). The satisfying principle in capability learning. Strategic Management Journal, 21(10/11), 981-996.

Womack, J. P., Jones, D. T., \& Roos, D. (1990). The machine that changed the world. New York: Rowson Associates.

Zahra, S. A., Sapienza, H. J., \& Davidson, P. (2006). Entrepreneurship and dynamic capabilities: A review, model and research agenda. The Journal of Management Studies, 43(4), 917-956.

Zeitz, G., Mittal, V., \& McCauly, B. (1999). Distinguishing adoption and entrenchment of management practices: A framework for analysis. Organizational Studies, 20(5), 741-776.

Zhang, Q., Vonderembse, M. A., \& Lim, J.-S. (2003). Manufacturing flexibility: Defining and analyzing relationships among competence, capability, and customer satisfaction. Journal of Operations Management, 21(2), 173-191.

Sarah Jinhui Wu is an assistant professor of management systems in the Graduate School of Business Administration, Fordham University. She received her PhD in operations management from Michigan State University. Her research interests include operations strategy, supply chain integration and coordination, closedloop supply chain, and environmental management systems. She has published in the IEEE Transactions on Engineering Management, International Journal of Logistics Management, and Business Horizons.

Steven A. Melnyk is a professor of operations and supply chain management at Michigan State University. He has coauthored 14 books on operations and supply chain management. His research interests include supply chain design, metrics/system measurement, humanitarian/disaster relief supply chains, responsive supply chains, and environmentally responsible manufacturing. He has published over 75 refereed articles in numerous national and international journals. He sits on the editorial review board for Production and Inventory Management, the Journal of Humanitarian Logistics and Supply Chain Management, the Journal of Supply 
Chain Management, and the International Journal of Production Research. He is the faculty director of education for the Masco Leadership Program in Operations Management - a program recognized by Fortune as an example of the most effective relationship between an academic institution and industry.

Barbara B. Flynn is the Richard M. and Myra Louise Buskirk Professor of Manufacturing Management at the Kelley School of Business at Indiana University. She has published numerous articles in top journals including Management Science, Journal of Operations Management, Production and Operations Management, and others. She is director of the High Performance Manufacturing research group, which studies global manufacturing practices. She is past editor in chief of Decision Sciences, Journal of Innovative Education, and Quality Management Journal and currently serves as an associate editor of Decision Sciences and the Journal of Supply Chain Management and Production and Operations Management as well as serving on the editorial review board of many other journals. 